\title{
Evaluace tří výukových programů s tématikou permakultury
}

\section{Nikola Papežová}

\section{Envigogika 13 (2) - Recenzované články/ Reviewed Papers}

Publikováno / Published 20. 12. 2018

DOI: $10.14712 / 18023061.571$

\begin{abstract}
Abstrakt
Př́spěvek se zabývá evaluací tři environmentálních výukových programů vytvořených na základě metodických materiálů, které vznikly v rámci projektu podpořeného MŽP "Přírodní architekti“, inspirovaného mezinárodním projektem "Children in permaculture“. Výukové programy byly vytvořeny pro žáky 4. a 5. ročníků a zaměřeny na seznámení s permakulturou, jejími principy a možným využitím pro každodenní život. $Z$ evaluace všech tří výukových programů formou pretestu a posttestu vyplývá, že všechny významně zvyšují znalosti žáků o dané problematice. Celkově Ize hodnotit nově vytvořené výukové programy jako přínosný doplněk pro rozšíření učiva základní školy.
\end{abstract}

\section{Klíčová slova}

environmentální výuka; udržitelný rozvoj; efektivita výuky

\begin{abstract}
This research is focus at an evaluation of three environmental education programs. These are based on the methodological materials created within the framework of a project supported by ministry of the environment "Natural Architects", inspired by the international project "Children in permaculture". The tutorials were designed for pupils of the 4th and 5th grade and were focused on getting acquainted with permaculture, its principles and its use for everyday life. The evaluation of all three teaching programs in the form of pretest and posttest shows that all three programs significantly increase pupils' knowledge of the given subject. Overall, the newly created learning programs can be evaluated as a benefit supplement for the extension of the elementary school curriculum.
\end{abstract}

\section{Keywords}

environmental education; sustainable development; education efficiency 


\section{1. Úvod}

\subsection{Permakultura}

Permakultura představuje vytváření trvale udržitelných systémů a hledání cesty k soběstačnosti na základě úzkého propojení s přírodou. Jde o filosofii založenou na poznání, že příroda nás dokáže uživit, dáme-li jí př́ležitost. Slovo permakultura pochází z anglického sousloví permanent agriculture, v překladu trvalé zemědělství. Permakulturní principy vytvořil David Holmgrenen, a přispěl tak k vytvoření konceptu permakultury a celosvětovému hnutí. Těchto dvanáct principů permakulturního designu (viz obr. 1), které zformuloval ve své práci Permakultura - principy a cesty nad rámec trvalé udržitelnosti, se dá aplikovat na kteroukoli oblast lidské činnosti (výchova dětí, lidská sídla, ekonomické systémy a další) (Holmgren, 2006). Uplatňování permakulturních principů a etiky vede k environmentálně odpovědnému jednání a tím i k praktické ochraně životního prostředí (Lebo, 2012). Dle Hauserové (2018) je permakultura založena na pozorování a využívání přírodních koloběhů, vztahů a vazeb k designování všeho, co potřebujeme k životu: hojné a zdravé produkce potravin, bydlení, systémů poskytujících energii i samotných lidských komunit. Využívají se zde jak starobylé tradiční postupy, tak moderní technologie a poznatky současné vědy.

\begin{tabular}{|l|l|}
\hline Číslo & Permakulturní princip \\
\hline 1. & Pozoruj a jednej (Krása je v očích pozorovatele) \\
\hline 2. & Zachycuj a uchovej energii (Kuj železo, dokud je žhavé) \\
\hline 3. & Získej výnos (S prázdným žaludkem se špatně pracuje) \\
\hline 4. & $\begin{array}{l}\text { Usměrňuj sebe sama a přijímej zpětnou vazbu (Hříchy otců se projeví na dětech } \\
\text { do sedmé generace) }\end{array}$ \\
\hline 5. & Využívej obnovitelné zdroje a služby a važ si jich (Příroda sama ví, co dělá) \\
\hline 6. & Nevytvářej odpad (Kdo šetří má za tři. Jedna včasná záplata ušetří devět dalších) \\
\hline 7. & Postupuj od celku k detailưm (Jinak by pro stromy nebylo vidět les) \\
\hline 8. & Dej přednost začleňování před oddělováním (Více rukou, méně práce) \\
\hline 9. & $\begin{array}{l}\text { Využívej malých a pomalých řešení (Čím jsou výsledky větší, tím tvrději dopadají. } \\
\text { Pomalí a vytrvalí vyhrávají) }\end{array}$ \\
\hline 10. & Využívej rozmanitosti a važ si jí (Neukládej všechna vejce do jednoho košíku) \\
\hline 11. & $\begin{array}{l}\text { Využívej mezí a važ si okrajových systémů (Nemysli si, že jsi na správné cestě } \\
\text { jen proto, že je dobře vyšlapaná) }\end{array}$ \\
\hline 12. & $\begin{array}{l}\text { Využívej změnu a tvořivě na ni reaguj (Vize není o tom, jaké jsou věci nyní, ale } \\
\text { jaké budou) }\end{array}$ \\
\hline
\end{tabular}

Obrázek 1. Permakulturní principy dle Holmgrena (2006)

„Children in permaculture“ (Children in permaculture, 2018) je mezinárodní projekt podpořený evropským programem Erasmus+. V rámci České republiky je do projektu od 
roku 2015 zapojena organizace CEGV Cassiopeia. Ta spolupracuje s organizacemi z dalších čtyř evropských zemí (Velká Británie, Itálie, Rumunsko a Slovinsko) na vývoji metodických materiálů pro pedagogy celé Evropy, kteří chtějí předávat dětem základy permakultury ve výuce. Těmito metodickými materiály byl inspirován projekt "Přírodní architekti", v jehož rámci byly vytvořeny tři výukové programy zaměřené přímo na seznámení se s permakulturou, s jejími principy a využitím pro každodenní život.

\subsection{Ekologické výukové programy}

Výukové programy (VP), jež probíhají v centrech ekologické výchovy, kladou důraz zejména na vztah člověka k životnímu prostředí, podporují uvědomění si spoluzodpovědnosti lidí za současný i budoucí stav a vedou děti k pozorování prírody (MŽP, 2011). Výukové programy Ize tak chápat jako jeden z možných nástrojů ochrany životního prostředí. Tento typ výuky by také měl přispívat ke zvýšení informovanosti účastníků o permakultuře a $\mathrm{k}$ jejich schopnosti spolupracovat $\mathrm{s}$ prírodou a učit se od ní v prírodním prostředí (Smrtová a kol., 2012). Cílem projektu bylo proto vytvořit takové VP, které vedou děti nejenom k osvojování návyků, ale také pochopení principů motivujících k environmentálně odpovědnému jednání.

Cíl provedeného výzkumu spočíval $v$ ověření, jestli nově zavedené VP prokazatelně zvyšují informovanost a znalosti o možnostech trvale udržitelného způsobu života, o tom, co je to permakultura, jaké jsou její principy a jak Ize tyto principy využít v praxi; patří sem i přehled o spotřebě a dostupnosti fosilních paliv a s tím spojené problémy se znečištováním životního prostředí a problematika prodeje a nákupu potravin z dovozu a od místních farmářů. Pochopení těchto zásad patří mezi vzdělávací cíle vycházející z konceptu permakultury Davida Holmgrena (2006).

Nově byly vytvořeny tři výukové programy. Jde o program „Pozoruj a jednej" zaměřený na předávání etických zásad a principů směřujících $\mathrm{k}$ vytváření trvale udržitelných systémů na základě spolupráce $s$ prírodou. Seznamuje s účinnými nástroji pro podporu šetrnějšího způsobu života. Program "Přírodní architekti" se pak soustředuje na uplatňování permakulturních principů a etiky při vytváření vlastní zahrady a stavbě domu, tj. hlavně na trénink uplatňování účinných postupů, které povedou k ohleduplnějšímu způsobu života a jejich využívání v praxi. Třetí program nese název „Až dojde ropa“; ten se zabývá především problematikou nadměrné spotřeby ropy, znečištování a také ekologicky šetrnými stravovacími návyky. Program motivuje účastníky přemýšlet o nadměrné spotřebě potravin a jejich cestě až k nám na talír.

\section{Metoda}

Celkově byly vytvořeny tři výukové programy pro žáky 4. a 5. ročníků v délce $2-3$ hodin. Programy na sebe postupně navazují. Dle B. S. Blooma se kognitivní činnost žáků během výuky člení do hieraticky uspořádaného systému, a tento systém tak slouží k logickému propojení učiva a činnosti žáků (Kalhoust \& Obst, 2009). Hierarchické uspořádání $\checkmark$ podobě pyramidy vychází z šesti po sobě jdoucích cílù. Pořadí programů bylo sestaveno v souladu s tímto schématem (viz obr. 2). 


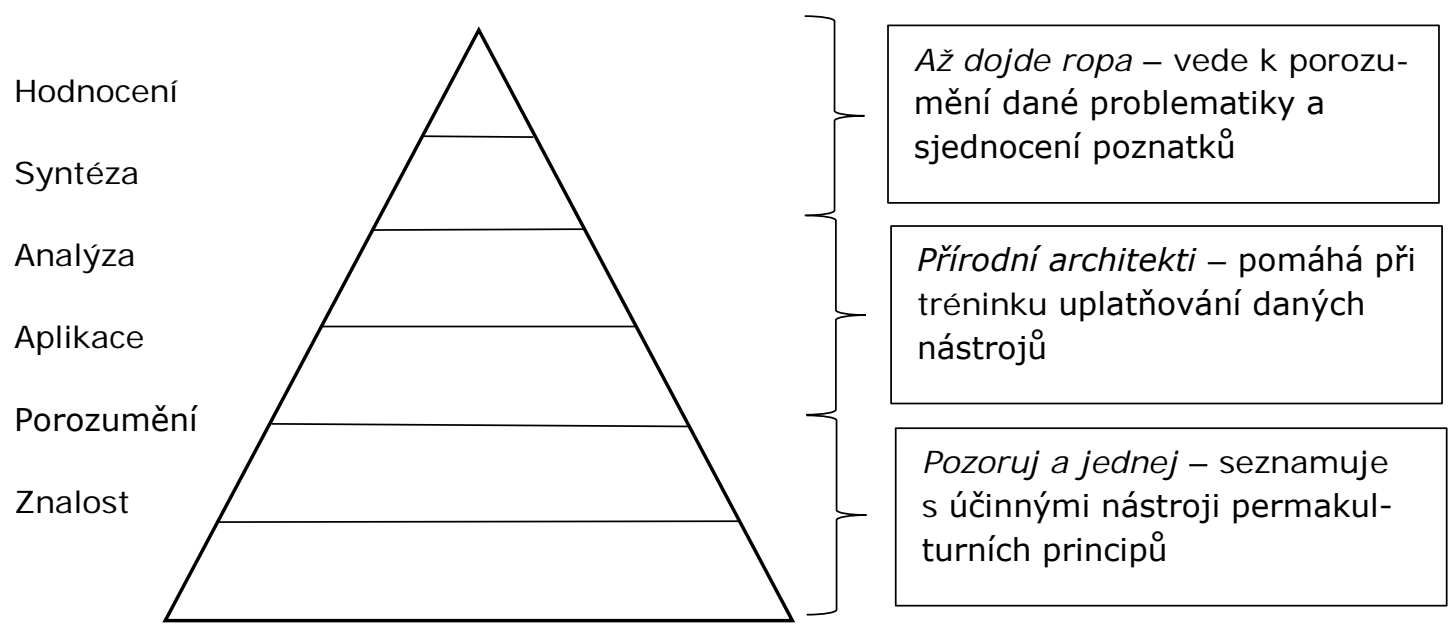

Obrázek 2. Bloomova hierarchie kognitivních cílů propojená s výukovými programy. Převzato a upraveno dle Kalhousta \& Obsta (2009).

J ednotlivá témata $v$ programech jsou žákům priibližena pro ně srozumitelnou formou se značným zjednodušením problematiky (pomocí her) a korespondují s potřebami pedagogů a cíli danými Rámcově vzdělávacím programem pro základní vzdělávání (Jeřábek a Tupý, 2005).

V prvním programu „Pozoruj a jednej" se žáci vžijí do příběhu rodiny Principálových, která jim představí dvanáct principů fungujících v přírodě i u nich doma: napríklad, že je lépe nejprve pozorovat a až poté jednat; dělat malé a pomalé kroky; ujistit se, že z práce, kterou děláme, budeme něco mít; používat obnovitelné zdroje a materiály aj. Žáci si vyzkoušejí, jak s prírodou spolupracovat a porozumět př́rodním zákonitostem. Program formou drobných her v terénu nabízí a představuje jednu z možných odpovědí na globální problémy - plánování ve spolupráci s prírodou a permakulturou. Žáci jsou během programu seznámeni s účinnými nástroji podporujícími šetrný zpưsob života. Ve druhém programu „PY̌írodní architekti" se žáci stanou architekty, kteří navrhují vlastní domek šetrný k nim i k prírodě. Rozdělí se na více skupin (rodin) a pustí se do stavby podle prírodních principů. Celá třída tak vytvoří spolupracující vesničku. Ve způsobu hospodaření s teplem, odpady a vodou berou inspiraci ze světa zviŕat a rostlin.

Cílem tohoto programu je vytvoření místa, kde budou spokojeni jak oni, tak jejich sousedé a vše živé okolo. Žáci uplatňují permakulturní principy v praxi. V programu „Až dojde ropa" žáci hrají simulační hru $v$ terénu o těžbě ropy a cestě zboží ke spotřebiteli. Promění se $v$ těžaře ropy i $v$ dopravní prostředky. Hledají odpovědi na to, kolik má za sebou potravina kilometrů, zdali pochází z dalekého Peru, Evropy nebo ze sousedovy zahrádky. Během programu se žáci dozvědí, jak to poznat a proč je to vlastně důležité. Společně pak hledají možnosti jak zkrátit cestu jídla.

Žáci by dle předpokladu měli v rámci drobných a simulačních her získat vztah ke zvolenému problému a prostřednictvím dalších aktivit pak získat přiležitost jej blíže zkoumat a propojovat s praxí. Takto o tom píší i Bardwell a kol. (1994), kteří zdůrazňují, že je velmi důležité, aby žák při výukovém programu pracoval $s$ konkrétními problémy. V souladu $S$ Hungerfordem \& Volkovou (1990) mají znalosti získané během programu následně zvyšovat 
míru proenvironmentálního jednání účastníků. Tvůrci výukových programů očekávají, že pomocí nich dojde $k$ naplnění očekávaných výstupů a dosažení předpokládaného výsledku, tj. k utváření a zvýšení úrovně environmentální gramotnosti, jak je znázorněno v následujícím schématu (viz obr. 3).

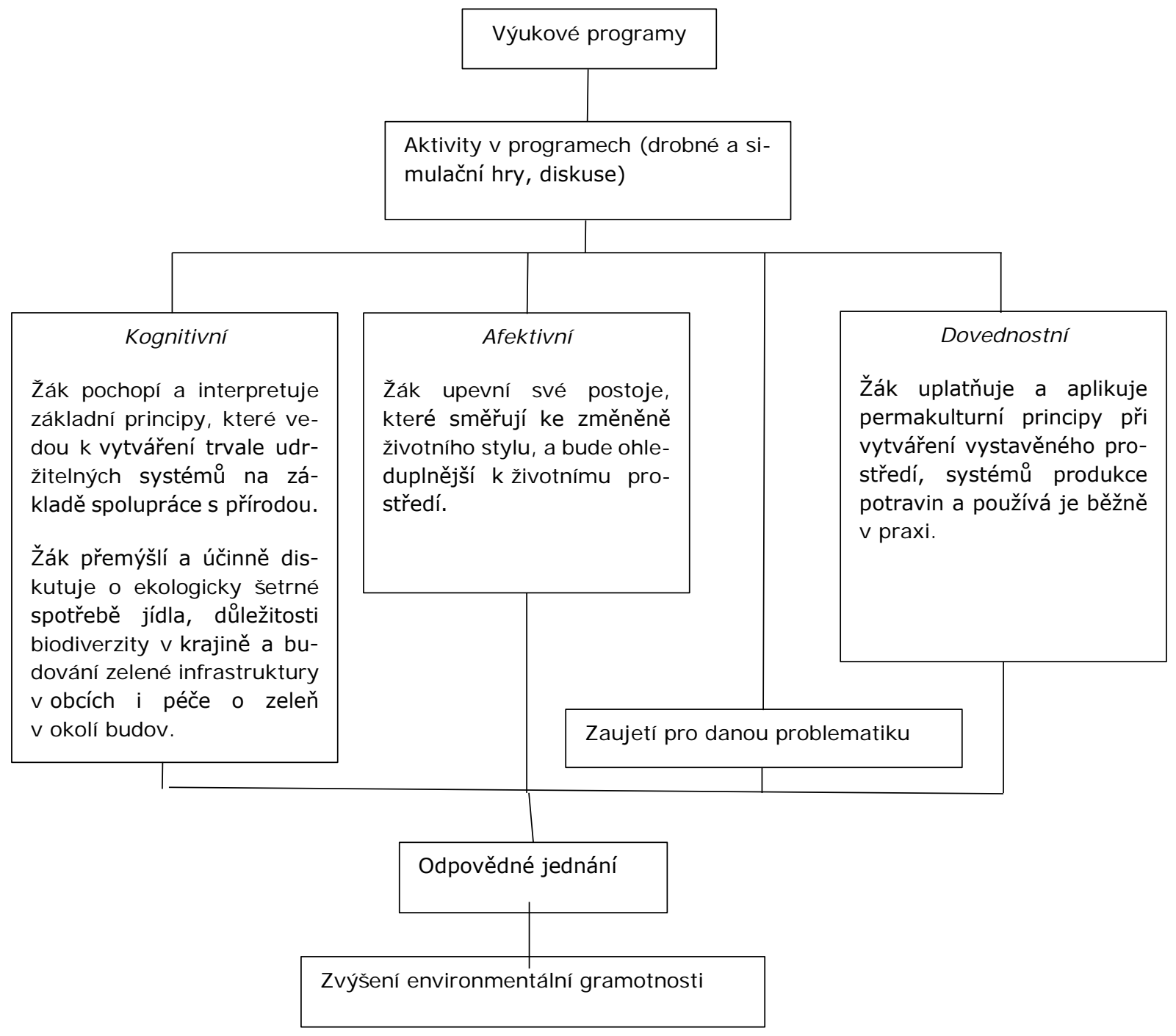

Obrázek 3. Schéma znázorňuje, jak dojde $\mathrm{k}$ dosažení předpokládaného výsledku, kterým je zvýšení úrovně environmentální gramotnosti žáků.

Lektoři Centra ekologické a globální výchovy Cassiopeia doporučují postupně projít všemi třemi programy, aby došlo k naplnění všech kognitivních cílů, je ale možné uskutečnit pouze některý z nich.

\section{Postup výzkumu}

Ověřování výukových programů proběhlo na základě kvantitativní evaluace, při níž žáci formou pretestu a posttestu vyplňovali nestandardizovaný dotazník. Použité dotazníky (př́loha 1) vytvořily autorky výukových programů z CEGV Cassiopeia v Českých Budějovicích. 
MŽP ČR (2011) uvádí jako jeden z cílů environmentální výchovy, vzdělávání a osvěty (EVVO) naučit následující generaci žít podle principů trvale udržitelného rozvoje, toto MŽP uvádí i ve Státním programu na léta 2016-2025 (MŽP, 2016). S ohledem na jeho cíle, nově vytvořené programy přispěly v několika oblastech, představených viz obr. 4.

\begin{tabular}{|c|c|}
\hline $\begin{array}{l}\text { Označení úkolu/opatření v dokumentu } \\
\text { EVVO a environmentálního poraden- } \\
\text { ství na léta } 2016-2025\end{array}$ & $\begin{array}{l}\text { Výstup programů pro jejich naplnění } \\
\text { nebo přispění }\end{array}$ \\
\hline $\begin{array}{l}\text { Úkol 5.2.8.2: „Podpořit vzdělávání a osvětu o hodnotě } \\
\text { a potřebě ochrany biodiverzity, „divočiny“ a samovol- } \\
\text { ných prrírodních procesů.“ }\end{array}$ & $\begin{array}{l}\text { Aktivity v programu „Pozoruj a jednej“ jsou zaměřeny } \\
\text { na předávání principů vedoucích k vytváření trvale } \\
\text { udržitelných systémů na základě spolupráce s př́ro- } \\
\text { dou. }\end{array}$ \\
\hline $\begin{array}{l}\text { Opatřeni } 5.3 .5: \text { „Zavést tématiku vystavěného pro- } \\
\text { středí, veřejného prostoru, architektury, urbanismu a } \\
\text { krajinářské tvorby do EVVO, do formálního i nefor- } \\
\text { málního vzdělávání.“ }\end{array}$ & $\begin{array}{l}\text { Aktivity v programu „Přírodní architekti“ jsou zamě- } \\
\text { řené na uplatňování permakulturních principů a etiky } \\
\text { při vytváření vystavěného prostředí a systémů pro- } \\
\text { dukce potravin. Program pomáhá zavést tématiku } \\
\text { tvorby vystavěného prostředí inspirovaného prrírodou } \\
\text { do EVVO. }\end{array}$ \\
\hline $\begin{array}{l}\text { Opatřeni 5.4.1: „Podporovat vzdělávání, výchovu, } \\
\text { osvětu a poradenství propojené s dobrou praxí a inova- } \\
\text { cemi v místní a ekologicky šetrné spotřebě potravin } \\
\text { (,jídlo z blízka“) a dalších } 44 \text { komodit (energií, techno- } \\
\text { logií a služeb) přispívající k udržitelnosti regionu (eko- } \\
\text { nomika, společnost, zdraví, př́roda a krajina) - pro ve- } \\
\text { řjnost, veřejné instituce, firmy, žáky, učitele, nepeda- } \\
\text { gogické pracovníky škol, např. pracovníky školních jí- } \\
\text { delen.“ }\end{array}$ & $\begin{array}{l}\text { Program „Až dojde ropa“ podporuje vzdělávání, vý- } \\
\text { chovu a osvětu mezi pedagogy a žáky základních škol } \\
\text { ohledně místní a ekologicky šetrné spotřeby jídla, pro- } \\
\text { gram „Př́rodní architekti“ zase zejména v souvislosti } \\
\text { s tématem př́roda a krajina. }\end{array}$ \\
\hline $\begin{array}{l}\text { Opatřeni 5.5.4: „Podporovat vzdělávací programy a } \\
\text { osvětové kampaně zaměřené na zavádění mitigačních } \\
\text { opatření, tedy opatření eliminujících emise skleníko- } \\
\text { vých plynů (zejména v oblasti obnovitelných zdrojů } \\
\text { energie, energetických úspor, čisté mobility, produkce } \\
\text { potravin a prevence vzniku odpadů), dále pak opatření } \\
\text { eliminující ostatní znečišt'ující látky (zejména u lokál- } \\
\text { ních topeništ'), vlivy různých kategorií zdrojů na kva- } \\
\text { litu ovzduší, zdraví lidí a ekosystémy. Zajištovat pro } \\
\text { tyto aktivity dostupná aktuální data a informace (statis- } \\
\text { tiky apod.)“ }\end{array}$ & $\begin{array}{l}\text { Program „Až dojde ropa“ orientovaný zejména na uvě- } \\
\text { domění si problematiky klimatické změny. Program } \\
\text { „Pozoruj a jednej““ seznamuje s účinnými nástroji mo- } \\
\text { tivujícími k šetrnějšímu způsobu života. Program „Př́i- } \\
\text { rodní architekti““ pomáhá při tréninku uplatňování } \\
\text { těchto nástrojů. }\end{array}$ \\
\hline $\begin{array}{l}\text { Opatřeni } 5.5 .5 \text { : „Podporovat vzdělávací programy a } \\
\text { osvětové kampaně zaměřené na zavádění adaptačních } \\
\text { opatření v krajině i v zastavěném území, tedy opatření } \\
\text { podporující přizpůsobení člověka projevům a dopadům } \\
\text { změny klimatu podle Strategie přizpůsobení se změně } \\
\text { klimatu v ČR (zejména v oblasti protipovodňových } \\
\text { opatření a prrípravy na suchá a horká období, zachytá- } \\
\text { vání a využívání dešt'ové vody, noční chlazení a denní } \\
\text { stínění, budování zelené infrastruktury v obcích, péče o } \\
\text { zeleň v okolí budov apod.) Motivovat školy k začlenění } \\
\text { těchto témat do ŠVP a k dialogu v rámci místa a regi- } \\
\text { onu.“ }\end{array}$ & $\begin{array}{l}\text { Program „Př́írodní architekti““ zaměřený na plánování } \\
\text { zahrady a domu vede k uvědomění si důležitosti diver- } \\
\text { zity v krajině a budování zelené infrastruktury v obcích } \\
\text { i péče o zeleň v okolí budov nebo zachytávání a vyu- } \\
\text { živání dešt'ové vody pro zvládání extrémních období - } \\
\text { povodně, sucha. }\end{array}$ \\
\hline
\end{tabular}

Obrázek 4. Znázornění, jak nově vytvořené výukové programy přispívají k naplnění daných opatření nebo úkolů, jenž jsou naplánované ve státním programu EVVO a poradenství na léta 2016 - 2025. 
Nově vytvořené programy byly pilotně odzkoušeny vždy se dvěma skupinami žáků čtvrté či páté třídy ze základních škol v Českých Budějovicích nebo blízkém okolí, které se ke spolupráci v projektu dobrovolně přihlásily. Vždy proběhly dvě pilotní realizace daného programu, pokaždé s jinou tř́́dou vedenou jiným pedagogickým doprovodem, ale se stejným lektorem, a to v termínech od 6. června 2017 do 18. října 2017 v CEGV Cassiopeia v Českých Budějovicích. Pro vyhodnocení, zda byly splněny kognitivní cíle prostřednictvím nově vytvořených VP, bylo použito dotazníkové šetření. Tvrzení $v$ dotaznících vycházela $z$ obsahů VP (př́loha 1 ). Sběr dat měl design v podobě pretestu a posttestu. Žáci tedy vyplňovali dotazník před zahájením samotného programu a pak následně několik dní po jeho absolvování (viz obr. 5). Díky této metodě sběru dat mohou být měřeny změny výsledků (Mertens, 2015).

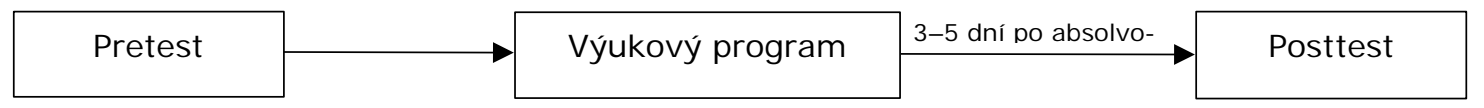

Obrázek 5. Schéma designu sběru dat

Tvưrci výukových programů vytvořili tři varianty nestandardizovaného dotazníku (pro každý VP zvlášt'), v němž žáci vyjadřovali svoji míru souhlasu a nesouhlasu s tvrzením na tř́stupňové škále Likertova typu (souhlasím, nevím, nesouhlasím), která se často aplikuje při zjištování kognitivní složky (Výrost a Slaměník, 2008). Celkové skóre činil součet žákem získaných bodů. Sběr dat proběhl $v$ rámci pretestu před uskutečněním programu $v$ místě konání a poté $s$ odstupem tř́ až pěti dnů po jeho ukončení v rámci posttestu, přičemž žáci v obou př́padech vyplňovali tentýž dotazník. Efektivita programů byla hodnocena na základě celkově získaných bodů z dotazníku v rámci pretestu a posttestu použitím párového t-testu. Parametrické t-testy byly použity i pro ordinální data, protože jsou dostatečně robustní vǔči narušení předpokladů (Meek a kol., 2007; Norman, 2010). Hladina významnosti byla stanovena na $0,05(a=0,05)$. Celkem se všech tř́ programů zúčastnilo 125 žáků, tj. programu „Až dojde ropa“ 39 žáků, „Pozoruj a jednej“ 45 žáků, a „Přírodní architekti“ 43 žáků. Samotné vyplnění dotazníků zabralo žákům cca 10 minut. Analýzy dat byly provedeny $v$ programu Statistica.

\section{VP „Pozoruj a jednej“}

\begin{tabular}{|c|c|c|c|}
\hline Tvrzení & Nesouhlasím & Nevím & Souhlasím \\
\hline $1,3,5,6$ & 1 & 3 & 5 \\
\hline 2,4 & 5 & 3 & 1 \\
\hline
\end{tabular}

\section{VP „Př́ŕrodní architekti““}

\begin{tabular}{|c|c|c|c|}
\hline Tvrzení & Nesouhlasím & Nevím & Souhlasím \\
\hline $1,2,3,4$ & 1 & 3 & 5 \\
\hline
\end{tabular}

\section{VP „Až dojde ropa“}

\begin{tabular}{l|l|l|l}
\hline Tvrzení & Míra souhlasu & Nesouhlasím & \multicolumn{2}{|c|}{ Nevím } & Souhlasím \\
\hline $2,4,5,6$ & 1 & 3 & 5 \\
\hline 1,3 & 5 & 3 & 1
\end{tabular}

Obrázek 6. Přehled bodování jednotlivých odpovědí. 


\section{Výsledky}

\subsection{Analýza výsledků programu Pozoruj a jednej}

Žáci mohli v pracovním listě vytvořeném pro program „Pozoruj a jednej" získat celkem 30 bodů. Na základě statistického hodnocení (párový t-test) Ize konstatovat průkazný vliv absolvování programu ( $t=-6,69$; $\left.\mathrm{sv}=43 ; \mathrm{p}<10^{-6}\right)$, kdy během posttestu dosahovali žáci významně více bodů (viz obr. 7). Reliabilita pro pretest měla hodnotu 0,55 a pro posttest hodnotu 0,83 . Absolvování programu má vliv na pochopení etických zásad a principů směřujících $\mathrm{k}$ vytváření trvale udržitelným systémům. Dále pak žáky seznámil s účinnými nástroji pro podporu šetrnějšího způsobu života.

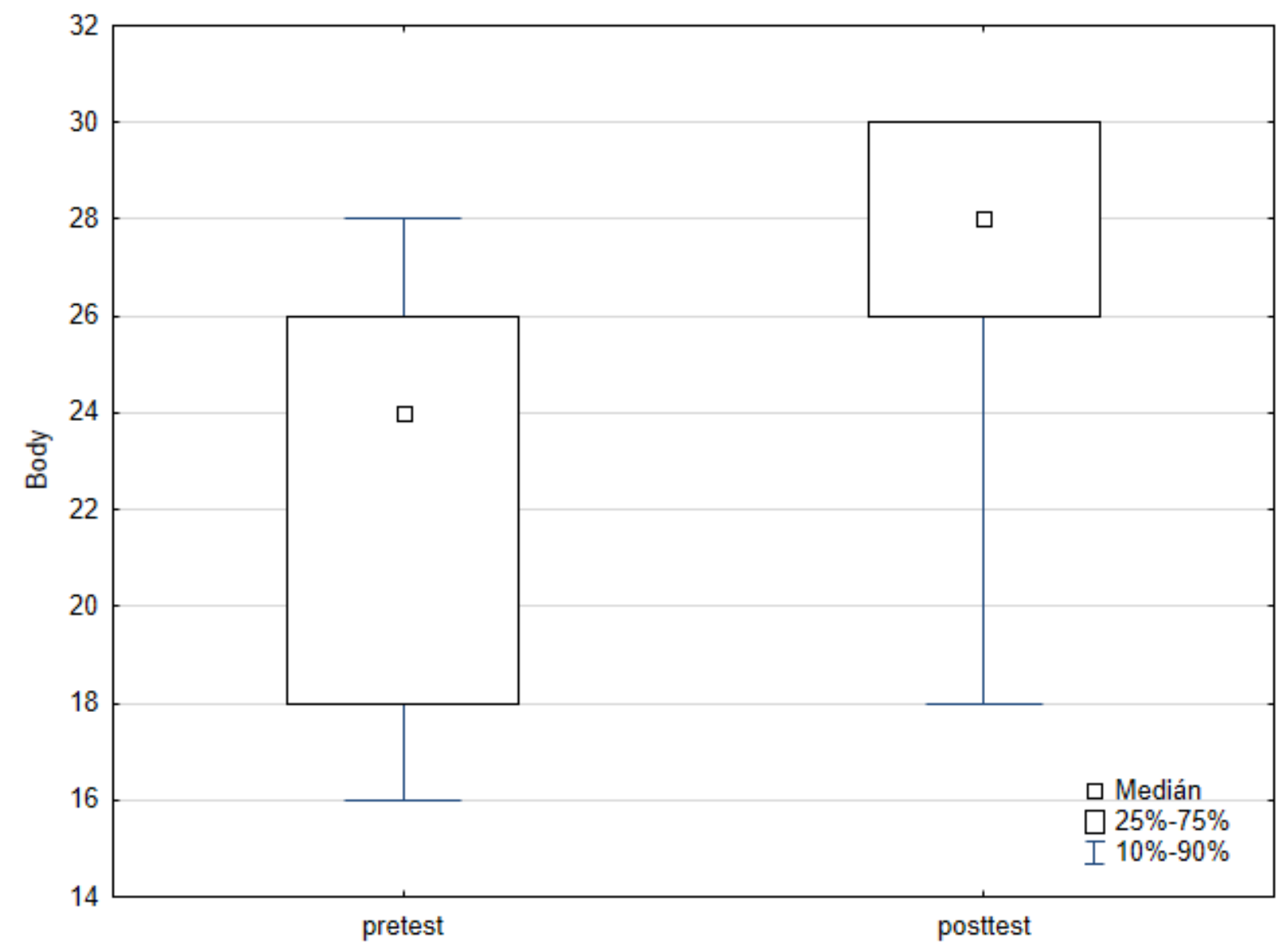

Obrázek 7. Celkové výsledky programu „Pozoruj a jednej“. V posttestu dosáhlo více než $75 \%$ žáků bodového zisku 26 a více. Rozdíl mezi pretestem a posttestem byl statisticky průkazný $\left(\mathrm{p}<10^{-6}\right)$.

\subsection{Analýza výsledků programu Př́ŕrodní architekti}

V pracovním listě programu „PY̌írodní architekti” mohli žáci získat celkem 20 bodů. Na základě statistického hodnocení (párový t-test) Ize konstatovat průkazný vliv absolvování programu $\left(t=-4,57 ; \mathrm{sv}=42 ; \mathrm{p}<10^{-5}\right)$, kdy více než $75 \%$ žákủ dosáhla během posttestu na maximální počet bodů (viz obr. 8). Reliabilita pro pretest měla hodnotu 0,63 a pro posttest hodnotu 0,84. Program ovlivňuje uplatnění účinných permakulturních principů a etiky při vytvoření vlastní zahrady a stavby domu v praxi. 


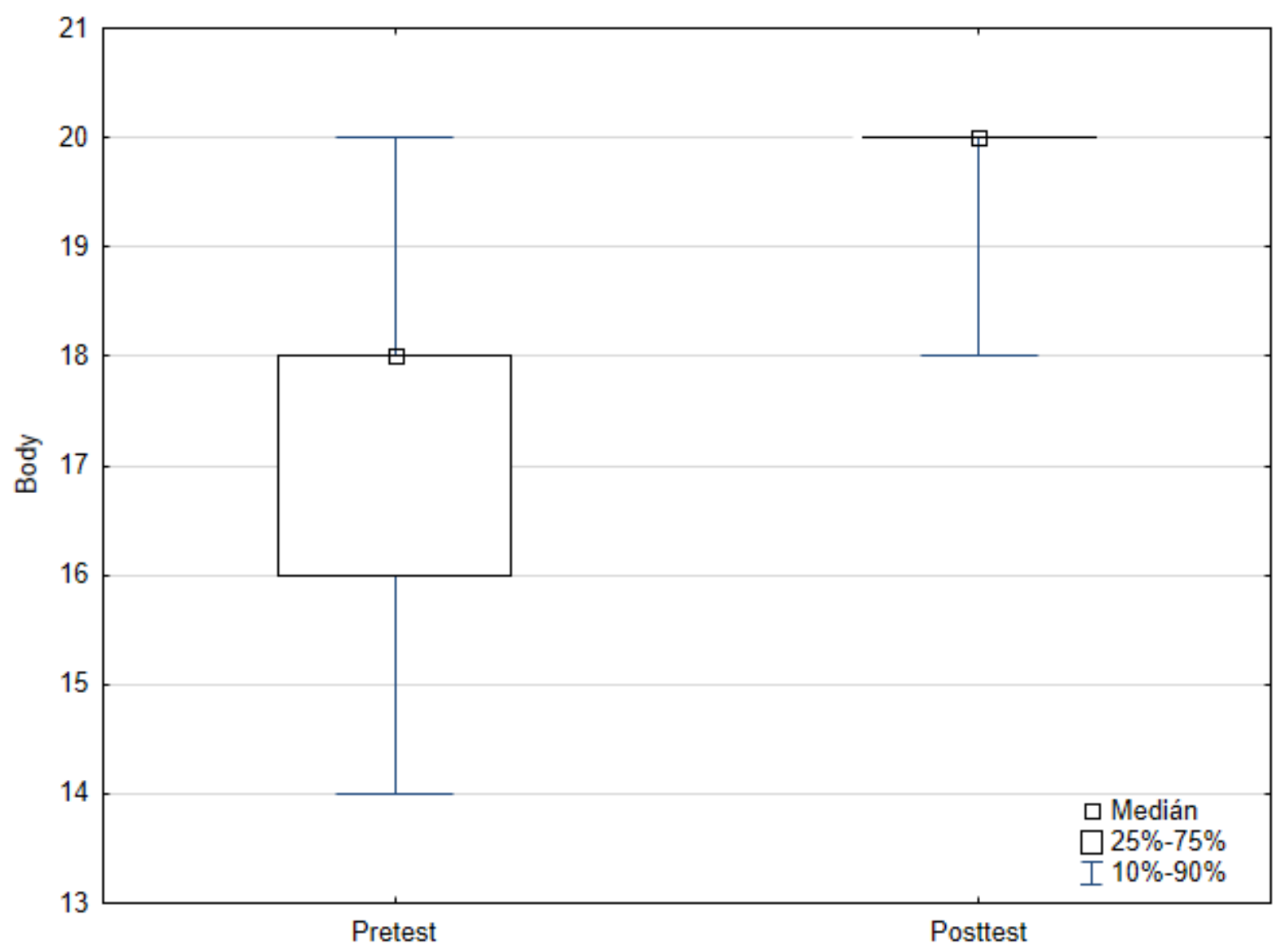

Obrázek 8. Celkové výsledky programu „Přírodní architekti“. I během pretestu dosahovali žáci poměrně vysokého bodového zisku, v posttestu již více než $75 \%$ žáků dosáhlo na maximální počet bodů. Rozdíl mezi pretestem a posttestem byl statisticky průkazný $\left(p<10^{-5}\right)$.

\subsection{Analýza výsledkư programu Až dojde ropa}

V pracovním listě „Až dojde ropa“ mohli žáci obdržet maximální počet 30 bodů. $\mathrm{Na}$ základě statistického vyhodnocení (párový t-test) Ize konstatovat průkazný vliv absolvování programu $\left(t=-5,48 ; \mathrm{sv}=37 ; \mathrm{p}<10^{-6}\right)$, $\mathrm{kdy}$ během posttestu dosahovali žáci průkazně více bodů (viz obr. 9). Reliabilita pro pretest měla hodnotu 0,21 a pro posttest hodnotu 0,37. Výukový program ovlivnil u žáků vnímání problematiky spotřeby ropy, ekologicky šetrnou spotřebu jídla a znečištování ovzduší. 


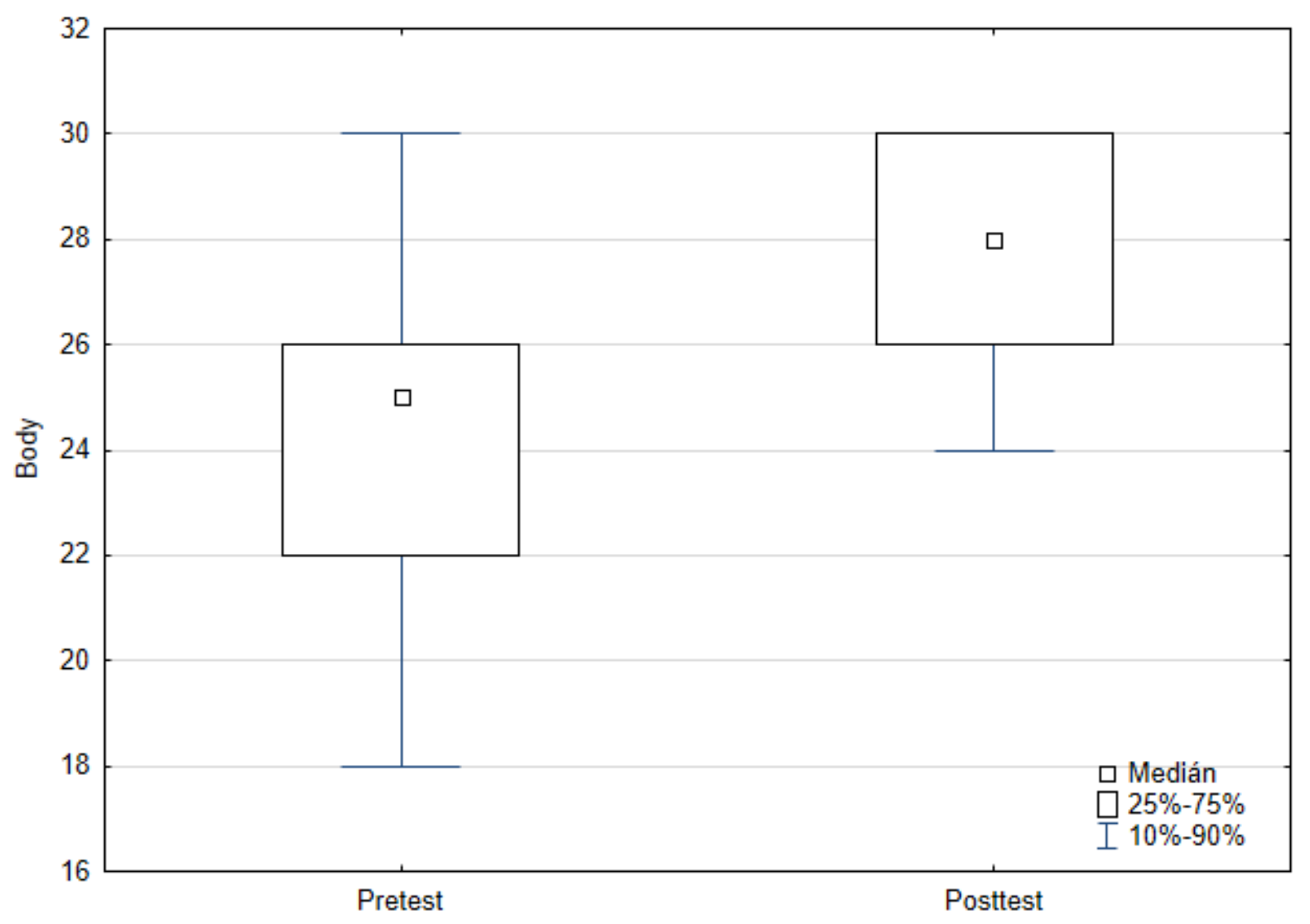

Obrázek 9. Celkové výsledky programu „Až dojde ropa“. Ačkoli i během pretestu žáci dosáhli vysokého bodového zisku, v posttestu dosáhlo více než 75\% žáků bodového skóre 26 a více bodů. Rozdíl mezi pretestem a posttestem byl statisticky průkazný $\left(p<10^{-6}\right)$.

\section{Diskuse}

Evaluace je proces kritického prověřování programu, jehož hlavním cílem je zvýšení efektivity programu. Zahrnuje především sběr a analýzu informací o programu včetně jeho účinnosti (Ecosystem, 2004). Dle Činčery (2008b) využívají střediska environmentální výchovy nejčastěji jeden ze čtyř typů evaluace. První typ evaluace hodnotí program lektor subjektivním nestrukturovaným pozorováním. Druhý typ evaluační strategie - lektoři provádějí náslech, při němž využívají nestrukturované nebo strukturované pozorování. Třetí typ je vyhodnocování programu na základě dotazování účastníků během programu. Poslední možnou strategií je využití externích evaluátorů. Tento poslední typ evaluace není v České republice $v$ oblasti environmentální výchovy př́liš rozšíren. Evaluace je přitom základním nástrojem, který v procesu kritického prověřování efektivity programů poskytuje jejich tvůrcům zásadní zpětnou vazbu $\mathrm{k}$ dalším úpravám a vývoji programu.

U nás se tímto typem výzkumu zabýval např. Hromádka (2010), který zjištoval vliv environmentální výchovy na vědomosti, postoje a chování u žáků druhého stupně. Zjistil slabý vztah mezi vědomostmi a postoji, také mezi postoji a chováním, ovšem neprokázal vztah mezi vědomostmi a chováním. Sledováním environmentálních postojů a jednání stu- 
dentů středních škol zaměřených na environmentální vzdělávání ve srovnání s těmi bez environmentální profilace se zabýval Bezouška \& Činčera (2007). Výsledky jejich šetření neprokázaly statisticky významný rozdíl mezi oběma skupinami. Schovajsová (2010), nezjistila rozdíly mezi vědomostmi, postoji a chováním u žáků ze škol prohlubujících a neprohlubujících environmentální výchovu. Tyto školy byly definovány jako splňující dané kritérium (např. zařazení do Klubu ekologické výchovy, M.R.K.E.V., Ekoškola), avšak skutečná míra environmentální výuky či výchovy stanovená nebyla. Evaluace mezinárodního programu GLOBE ukazuje, že program rozvíjí znalosti žáků, ale nemá významnější vliv na jejich výzkumné dovednosti, kterým se program do značné míry věnuje (Winklerová, 2015). V ekologickém středisku Jizerka byly evaluovány dva programy v rámci projektu Člověk a krajina Jizerských hor. Bylo zjištěno, že tyto programy mají reálný dopad na většinu měřených proměnných (Činčera, 2011b).

V zahraničí proběhly podobné evaluace výukových programů. V letech 2010 - 2011 proběhla $v$ Irsku evaluace programu Green Schools ( $v$ ČR známý pod pojmem Ekoškola). Míra dopadu programu na porozumění a znalosti byly u skupin s vlajkou zelené školy a bez ní velmi podobné. U studentů ze škol se zelenou vlajkou dosáhli významně vyššího skóre v oblasti chování a jednání a častěji diskutuji o problematice životního prostředí ( $O$ 'Mahony a Fitzegerald, 2001). Program Tree Keepers realizovaný společností The Greening of Detrioit zaznamenal vysoký účinek na zúčastněné pedagogy. Ti po jeho absolvování více používali př́rodu jako prostor pro pedagogické činnosti a někteří začali zahradničit. U žáků evaluace programu prokázala značný nárůst nových schopností, dovedností a znalostí (Plumb a kol. 2007). Další evaluace se zabývala programem Four Rs action program pro žáky ve věku 811 let. Realizovala jej Kalifornská organizace KIDS for the BAY. Účinek na znalosti byl měřen pomocí pretestu a posttestu, bylo zjištěno, že žáci získali požadované znalosti (KIDS for the BAY, 2012).

Žáci si po absolvování testovaných výukových programů s tématikou permakultury si osvojili nové vědomosti, které byli schopni si uchovat, zapamatovat a po určité době znova interpretovat. To bylo zjištěno na základě statistického hodnocení, které prokázalo signifikantní rozdíl mezi pretestem a posttestem. Nově vytvořené výukové programy Ize hodnotit jako vyhovující doplněk školních osnov.

\section{Závěr}

Programy s tématikou permakultury mohou zvyšovat informovanost o principech trvale udržitelného způsobu života $v$ míře odpovídající věku žáků. Zprostředkují pochopení etiky založené na péči o Zemi, o lidi a na sdílení. Umožňují žákům osvojit si nejen návyky, ale především principy vedoucí $k$ environmentálně odpovědnému jednání, jejichž uplatňování může přispět $\mathrm{k}$ lepšímu zvládnutí ekologické krize a důstojnému životu ve světě bez fosilních paliv. Žáci získávají vlastní zkušenosti s důsledky neodpovědné spotřeby a s uplatňováním možných řešení v každodenním životě, což podporuje vědomí o spoluzodpovědnosti za stav na Zemi. Je tak možné zvyšovat kvalitu vzdělávání prostřednictvím aktivizujících metod výuky. Žáci dostanou možnost učit se přímou zkušeností, aktivním zkoumáním, hrou, experimentem, osvojují si poznatky $\vee$ přirozených souvislostech. $\vee$ neposlední řadě dotyčné výukové programy vytvářejí vhodné podmínky pro emocionální propojení s př́rodou, což je jeden z důležitých předpokladů pro utváření environmentálně přiznivých postojů a zvyšování kvality lidského života. 


\section{Poděkování}

Studie byla podpořena projektem Grantové agentury Jihočeské univerzity GAJU 118/2016/S, dále byla pak tvorba výukových programů podpořena programem Ministerstva životního prostředí v rámci projektu NNO 63/32/17. V neposlední řadě patří poděkování realizátorům a tvůrcům výukových programů.

\section{Seznam literatury}

- Bardwell, L., V., et al. (1994). Environmental Problem Solving. Theory, Practice and Possibilities in Environmental Education. North American Association for Environmental Education, PO Box 400, Troy, OH 45373.

- Bezouška, A., \& Činčera, J. (2007). Vliv environmentální profilace středních škol na proenvironmentální postoje a jednání studentů. Envigogika, 2(3). doi: 10.14712/18023061.20

- Činčera, J. (2008b). Evaluační strategie středisek ekologické výchovy [online]. Envigogika. Praha: Centrum pro otázky životního prostředí Univerzity Karlovy. Roč. 3, 2008b, č. 2. Dostupné na: https://www.researchgate.net/publication/269527339_Evaluacni_strategie_stredisek_ekologicke_vychovy. ISSN 1802-3061.

- Činčera, J., (2011b). Vliv pobytového programu o Jizerských horách na proenvironmentální postoje a hodnoty. Envigogika. Praha: Centrum pro otázky životního prostředí Univerzity Karlovy [online], roč. 6, č. 3. ISSN 1802-3061. Dostupné z: http://www.czp.cuni.cz/envigogika

- Ecosystem Management Iniatiative Projects Ver 3. 0 (2004). ECOSYSTEM Management I niatiative. Measuring Progress. An Evaluation Guide for Ecosystem and Community based Projects. Ver. 3.0. [online]. Retrieved from:

http://www.snre.umich.edu/ecomgt/evaluation/documents/Measuring\%20Progress.pdf

- Hauserová, E. (2018). Co je permakultura?. Permakultura CS. [online]. [cit. 2. 2. 2018]. Dostupné z: http://www.permakulturacs.cz/article/14/co-je-permakultura

- Holmgren, D. (2006). Permakultura: principy a cesty nad rámec trvalé udržitelnosti. 1. vyd. Svojanov: PermaLot, 296 s.

- Hromádka, Z. (2010). Životní prostředí ve vědomostech, postojích a jednání žáků druhého stupně základní školy. Disertační práce, Brno: Masarykova univerzita, Pedagogická fakulta, $164 \mathrm{~s}$

- Hungerford, H., R., \& Volk, T., L. (1990). Changing Learner Behavior Through Environmental Education. The Journal of Environmental Education, 21 (3), 8-21. Retrieved from http://dx.doi.org/10.1080/00958964.1990.10753743

- Children in permaculture, (2018). [online]. [cit. 3. 2. 2018]. Dostupné z: http://www.childreninpermaculture.com 
- Jeřábek, J., \& Tupý, J. (2005). Rámcový vzdělávací program pro základní vzdělávání. Národní ústav pro vzdělávání, 2011-2014.

- Kalhoust, Z. \& Obst, O. (2009). Školní didaktika. 2. vyd. Praha: Portál, 447 s.

- KIDS FOR THE BAY, 2012 [online]. Dostupné z: http://www.kidsforthebay.org/site/programs/reduce-reuse-recycle-rot.shtml

- Lebo, N. (2012). Ecological literacy through permaculture. Green Teacher, (98), 34-37. Retrieved from https://search.proquest.com/docview/1267726166?accountid=9646

- Meek, G. E., Ceyhun, O. \& Dunning, K. (2007). Comparison of the t vs. Wilcoxon Signed-Rank Test for Likert scale data and small samples. Journal of Modern Applied Statistical Methods, 6(1), 90-106.

- Mertens, D., M. (2015). Research and Evaluation in Education and Psychology: Integrating Diversity With Quantitative, Qualitative, and Mixed Methods. Sage publications.

- MŽP ČR, 2011: Cíle a indikátory pro environmentální vzdělávání, výchovu a osvětu $v$ České republice. Praha: MŽP.

- MŽP ČR, 2016: Státní program environmentálního vzdělávání, výchovy a osvěty a environmentálního poradenství na léta 2016 - 2025. Praha: MŽP.

- Norman, G. (2010). Likert scales, levels of measurement and the "laws" of statistics. Advances in health sciences education, 15(5), 625-632.

- O'Mahony, M. J.; Fitzgerald, F., (2001). The Performance of the Irish GreenSchools Programme. Results of the Green-Schools Research Projects [online]. Dostupné z: http://www.eltis.org/sites/default/files/case-studies/documents/ireland_research_report_2001_3.pdf

- Plumb, S., et al., (2007). The Greening of Detroit - Tree Keepers Kids [online]. Dostupné z: https://promiseofplace.org/sites/default/files/2018-06/Greening\%20Eval\%20Exec\%20Sum\%202007\%20rev\%20web.pdf

- Schovajsová, J., (2010). Současný stav environmentální výchovy na základních školách - vybrané aspekty environmentální gramotnosti dětí mladšího školního věku. Disertační práce. Olomouc: Univerzita Palackého, Pedagogická fakulta.

- Smrtová, E., Zabadal, R., \& Kováríková, Z. (2012). Za Naturou na túru: metodika terénní výuky. Apus.

- Výrost, J. \& Slaměník, I. (2008). Sociální psychologie. 2. přeprac. a rozš. vyd. Praha: Grada, 404 s.

- Winklerová, K. (2015). GLOBE: evaluace dlouhodobého vlivu programu na účastníky. Diplomová práce. Brno: Masarykova univerzita, Fakulta sociálních studií. 